\title{
Causes of Occupational Accidents and Injuries in Construction Industry in Jeddah City
}

\author{
Emad Abukhashabah, Ahmed Summan and Mansour Balkhyour \\ Environmental Sciences Department, Faculty of Meteorology and Arid Land Agriculture, King \\ Abdulaziz University, Jeddah, Saudi Arabia \\ asumman@kau.edu.sa
}

\begin{abstract}
This study identified the causes of accidents and injuries in the construction industry among 300 workers in Jeddah City, situated on the coast of the Red Sea of Saudi Arabia. Results from the questionnaire showed that the major cause of accidents and injuries is the lack of awareness about occupational safety and lack of experience among the workers $(>82 \%)$; and the most common type of accidents and injuries that occur in the construction industry, are workers falling from a height $(>80 \%)$, and electrical shock $(>60 \%)$. Recommendations to prevent accidents and injuries in this industry are provided in this paper.
\end{abstract}

Keywords. Construction industry- accidents and injuries in construction industry- causes of occupational accidents and injuries- occupational injuries- falling from a heightelectric shock incidents.

\section{Introduction \& Background}

The construction industry has shown phenomenal growth globally in last decade. It consists of activities such as construction, alterations, and/or repairs. Examples include various projects like residential construction, health-care and, educational facilities, airports, bridges, roadways, excavations, demolitions, and large-scale painting jobs (Prasad and Rao, 2013; OSHA, 2018; NIOS, 2018). The construction industry has however been classified as a high-risk industry (OSHA, 2018; NIOS, 2018; Pinto et al., 2011). The rate of the occupational injuries and worker accidents in construction locations is the highest compared to all other workplaces. Although substantial improvement has been achieved in occupational safety, it is still challenging to manage and control the risks of such workplace activities (Sousa et al., 2014). The accidents in the construction industry often have severe consequences on the workers, their families and the public. This industry sometimes records almost six times as many fatalities per hour worked and twice as many disabling injuries, as most other industries (BLS, 2005; Kalatpour and Khavaji, 2016). For example, in the United States, in 2004, construction workers represented $7.7 \%$ of the total U.S workforce, whereas $22 \%$ of the nationally reported work-related deaths were recorded amongst these workers (Helander, 1991; BLS, 2005; Kalatpour and Khavaji, 2016). In the United Kingdom, death rates for the construction industry in 2006 were up by 3.7\% (Enshassi and Mohammaden, 2012), while in Malaysia and other places, the construction sector has become a major 
economic force revealing even worst numbers (Abdul Hamid, 2003).

It was found that in developing countries, attention to health and safety issues at such worksites is very low, most tasks are performed manually, occupational exposure to hazards is very high, and record- keeping is of poor quality when measured by international standards (Kalatpour and Khavaji, 2016; Tam, 2004; Roudsari and Ghodsi, 2005). There are about 10.3 million workers in the private sector of Saudi Arabia alone, while the number of injuries and accidents in the construction industry is much higher than any other industry in the country. For instance, in 2014, the reported number of occupational accidents and injuries across the private sector was 69,241 - the construction industry accounted for more than $51 \%$ of these accidents and injuries (GOSI, 2015; Mosly, 2015). One of the main factors for this high percentage of accidents and injuries in the construction industry, is the dynamic constantly changing work environment, where it is typical to have several teams working on different tasks in the same zone and changing as the project proceeds. The stress of meeting deadlines and avoid penalties is another major contributing factor (Kalatpour and Khavaji, 2016; Mosly, 2015; Gürcanli GE and Müngen, 2009; Im et al., 2009; Hare et al., 2006; Wadick, 2010).

Studies have generally identified two major types of accidents and injuries in this industry that involve construction workers. The first type is known as the stationary accidents occurring in the work zone, and the second type is traffic accidents, which involve a motorist and a construction worker (Mohan and Zech, 2005). The common construction accidents and injuries include exposure to hazardous materials, electrical shock, getting hit by moving equipment, falling from a height, vehicle accidents, fractures, burns, sunstroke, amputation, being struck by heavy construction equipment, bruising, fainting, coma and death (OSHA, 2018; Cawley and Homce, 2003; Taylor et al., 2002; Tappin et al., 2004; Kadiri et al., 2014).

It has also been determined that most of these accidents and injuries occur due to a lack of knowledge, a lack of safety training, human errors, unskilled workers, lack of proper supervision, carelessness, apathy and downright recklessness, as well as poor and ineffective management at the sites (Helander, 1991; Enshassi, 2012; Sawacha et al., 1999).

In Saudi Arabia, and in Jeddah City specifically, the construction industry is one of the most important and fastest growing industries, where thousands of national and foreign workers are involved in hundreds of challenging and constantly changing tasks. In fact, foreign workers represent the majority of the workforce in this industry in almost all categories (e.g., management, contracting, sub-contracting, and labor). Most of these workers are from different backgrounds, unskilled or not trained at all to perform construction operations and tasks, which can put them at high risk (Mosly, 2015). Moreover, the environmental work conditions in Jeddah City are harsh due to the hot climate, where most of the construction projects are performed outdoors. Lack of awareness about occupational health and safety among employers and employees, lack of supervision, and unsafe worksites are amongst the challenges being faced in the whole country. Furthermore, Jeddah City is located in the western region of Makkah Al-Mukarramah that is responsible for the largest number (34\%) of the 2014 workplace accidents in Saudi Arabia (Mosly, 2015).

Therefore, the objectives of this study were to investigate and identify the causes of occupational accidents and injuries in the construction industry in Jeddah City, and to 
propose effective measures to minimize the number of accidents and injuries.

\section{Materials and Methods}

This study was conducted among 300 workers, selected randomly from two construction sites in Jeddah City (King Abdulaziz University and Jeddah University). A special questionnaire was developed by the authors and translated into three languages (Arabic, English and Urdu), and was distributed to the 300 workers from different departments at each work site such as security officers, electricians, painters, welders, safety supervisors, project managers, engineers, brick workers, heavy and light machine operators. Workers were requested to complete the questionnaires on their own as far as possible. The questionnaire is divided of into 4 sections as follows:

1) Personal information of the participant including his age, years of experience, level of education and training.

2) Causes of accidents (e.g., lack of awareness and experience, machines defect or errors, lack of personal protective equipment, no safety and health officer, unsafe work environment, lack of continuous training).

3) Types of accidents (e.g., falling from a height, getting hit with stationary equipment, hit with moving equipment, electric shock, exposure to chemicals, material handling incidents, car accidents).

4) Types of injuries (e.g., contusion or bruising, amputation, sunstroke, burns, fainting or coma, wounds, bleeding, suffocation, fractures).

Collected data from the questionnaire were statistically analyzed according to three major categories:

- The age of the worker (six scales: 20$25,26-31,32-37,38-43,44-49,50-55)$.
- Years of experience (five scales: 1-5 years, 6-11 years, 12-17 years, 18-23 years, 24-29 years).

- The level of education (None or Elementary education, Middle or Secondary education and Higher education).

Responses from the participants were presented in percentages (\%). The data obtained from the retrieved questionnaires was also statistically analyzed through correlation analysis. The significance levels of the correlation coefficient were $\mathrm{p} \leq 0.05$ and $\mathrm{p} \leq$ 0.01 (EL-Nakhlawy, 2010).

\section{Results and Discussion}

\subsection{Causes of Accidents and Injuries}

The results from the completed questionnaire from 300 participants regarding the causes of accidents and injuries from the two sites are shown in Tables 1, 4, and 7 . These results indicated that the main causes of accidents and injuries in the construction industry in Jeddah City include:

1) Lack of awareness and experience $(80 \%)$.

2) Machinery defect and errors (60\%)

3) Lack of training (30\%)

4) Lack of personal protective equipment PPE (25\%)

5) No safety and health officer or supervisor and unsafe work environment $(16 \%)$.

In fact, lack of awareness and experience represented the highest percentage among all other causes of accidents and injuries, which was also stated in the previous studies (Kalatpour and Khavaji, 2016; DeJoy et al., 2004; Tam et al., 2004; Tadesse and Israel, 2016). The results of the correlation tests also revealed a significant relationship between the lack of awareness and an unsafe work 
environment at a correlation coefficient $(\mathrm{p}<$ 0.01 and $p<0.05)$ and calculated $r=+0.82$.

Furthermore, workers strongly believed that the incorrect use of machine, and machine defects or malfunction are some of the most common causes of accidents in the construction industry $(60 \%)$, which points to a lack of proper supervision and/or the absence of proper machine maintenance at the worksite as part of safe work practices. The correlation between equipment and machines defect and unsafe work environment was also statistically significant at a correlation coefficient $(p<0.01$ and $\mathrm{p}<0.05)$ and calculated $\mathrm{r}=+0.98$. More interestingly, the correlation results indicated that the deficiency/errors of equipment and machines could be due to the operating/use by inexperienced and/or insufficiently trained workers at the worksite $(\mathrm{r}=+0.99$ to +1$)$. Most of the equipment and machines used in the construction industry require specialized training of the operators, and a lack of this crucial element, can result in serious occupational accidents and injuries.

Results showed that $25 \%$ of the workers from the two sites believed that there is a lack in providing quality and sufficient personal protective equipment (PPE) at their worksites, and more than $14 \%$ of the workers who completed our questionnaires agreed that the worksites are unsafe. Similarly, the correlation test results showed a significant relationship between unsafe work environments and the lack of PPE at correlation coefficient $(\mathrm{p}<$ 0.01 and $p<0.05$ ) and calculated $r=+0.95$. Earlier investigators concluded that the lack or absence of safety training programs, not using or the improper use of PPE, and a lack of occupational safety measures at the worksite, resulted in unsafe work environment that put workers at high risk (Kalatpour and Khavaji, 2016; Kadiri, 2014; DeJoy et al., 2004; Colak et al., 2004; Kumar and Kumar, 2012; Awad, 2013; Tadesse and Israel, 2016). Correlation test results also indicated that the lack of continuous training and the lack in providing PPE were significantly related to the absence or lack of a safety and health supervisor at the worksite $(\mathrm{r}>+0.98)$. Indeed, these are all critical aspects within the construction industry that can influence safety performance (Enshassi and Mohammaden, 2012).

From the results discussed above, it is evident that the provision of qualified safety and health supervisor at the worksite, intact equipment and machines, proper PPE, continuous training and awareness among the workers, are all crucial parts of a safe work environment. Adequate safety training for all workers at any construction or building site, and safety personnel on site, are both a must to raise the awareness level about safety and maintain safe working conditions for all (Mosly, 2015). This emphasizes the important role of the occupational safety and health authorities in the country and the role of the employer at each construction worksite.

\subsection{Types of Injuries}

Tables 3, 6, and 9 show that most workers agreed that the most common types of injuries that occur in the construction industry in Jeddah City include the following:

1) Electric shock (61\%)

2) Sunstroke (32.7\%)

3) Contusions or bruising (29.7\%)

4) Amputation and fractures (25.7\%)

5) Wounds and bleeding (24-23\%).

Other types of injuries (e.g., glass or dust in the eye, fainting, burns, suffocation) also occur, but at lower percentages than the ones mentioned above.

From these results electric shock represents the most common injury among workers/electricians in the investigated 
construction sites. Investigators from other countries (Kalatpour and Khavaji, 2016), indicated that electric shock is always a possibility at any construction site; however, the percentages of occurrence in most other countries are less than what it seems to be in Jeddah City.

Sunstroke was also one of the most common injuries among construction workers in Jeddah City. This is mainly due to the hot, sunny climate and outdoor worksites, where workers are directly exposed to the sun and heat. In Jeddah City, the air temperature can reach up to $47^{\circ} \mathrm{C}$ during the daytime in the summer (General Authority of Meteorology and Environmental Protection, 2018). Heat stress is another serious problem that can be suffered by construction workers under these environmental/climate condition. Sunstroke can be avoided at such sites by providing proper PPE to protect the head of the worker who is directly exposed to sun.

Some of the other types of injuries suffered such as bruising, fractures, wounds and amputations were found to represent a high percentage of injuries that construction workers can suffer. Previous studies indicated that lower body injuries (e.g., burns, fractures, amputations) represent one quarter to half of all injuries at construction sites; however, upper body injuries were found to represent more than half of all injuries, and often result in the disability of injured workers (Kartam and Bouz, 1998). Such injuries are mainly caused by the reckless action of the workers, a lack of or improper use of the required PPE. It was also found that injuries are often higher among young workers $(<35$ years old $)$ and workers with lower skill levels and/or insufficient experience (Kalatpour and Khavaji, 2016; Vouriot et al., 2004; Waehrer et al., 2007). In fact, our results confirm these findings; the most common causes of injuries included lack of awareness, inexperience, and lack of PPE. This study also indicated that the highest percentages of injuries occur among young workers $(<32$ years old) and among workers with less years of experience $(<11$ years) (Tables 3 and 6).

\subsection{Types of Accidents}

Tables 2, 5, and 8 show that the most common types of accidents that occur on construction sites in Jeddah City include the following:

1) Falling from a height (81\%)

2) Electric shock (38\%)

3) Falling equipment causing head injuries $(27 \%)$

4) Material handling incidents (25.33\%).

Other types of accidents (exposure to chemicals, hit with stationary equipment, and car accidents) also occur but at lower percentages $(11-24 \%)$. These findings indicated that falling from a height represents the most common accidents at the investigated construction sites, which confirm the results from other studies conducted at different construction sites worldwide, showing that the percentage of this incidence reached up to more than $50 \%$ of all accidents (Hinze et al., 2005; Abbas et al., 2013). Their results also showed that the incidence of falls from outer surfaces was $28.36 \%$, the rate of falls from buildings $19.39 \%$, and the incidence of falls from stairs $11.33 \%$. Falling from a height is mainly associated with the lack of PPE at the site and/or the improper use of the required PPE. Workers who are involved in highaltitude jobs that require working on the rooftop of a building or fixing and installing wall-tiles on the outer surfaces of a building, are required to wear a special safety belt, safety helmet, and other PPE, which is often totally neglected among the surveyed worksites. Similarly, the findings of an overview of accidents and injuries in the 
construction sector in Gaza city showed that $40 \%$ of accidents were caused by falls.

Although electric shock accidents represent $38 \%$ of all accidents at the investigated worksites, they are also considered the main cause of occupational deaths among construction workers (Enshassi and Mohammaden, 2012). Accidents that are related to tools and material handling occur at a higher percentage among young workers and workers with less experience at the worksite (Tables 2 and 5), as they are not trained properly and could behave irresponsible in the absence of safety supervision (Tables 1, 4 and 7). The workers' perception is always influenced by management roles and efforts towards safety issues at the worksite (Hassan et al., 2007). Furthermore, involving insufficiently trained workers in multiple and/or very difficult tasks, often cause them to neglect the required safety procedures. A number of these tasks might require a long duration using their hands, arms or be in physically awkward positions, and that increases the probability of physical injuries significantly (Hassan et al., 2007).

The results of this investigation therefore suggest the need to recommend several effective procedures to minimize the causes of reported accidents and injuries in the construction industry in Jeddah City.

\section{Recommendations}

The recommended procedures to minimize the causes of accidents and injuries can consist of several administrative and safety measures to be applied effectively. First of all, all employers need to honour the basic rights of all their employees, including their safety at work. The employer is responsible to provide the required personal protective equipment and maintain their validity for use, as well as for the training of workers in their proper use. The employer is required to enroll qualified and certified safety and health supervisors at his worksites, and assure that personnel is aware of his responsibilities and duties toward keeping the worksite safe, and also how to improve it to be healthier and safer for everyone. The employer is also ultimately responsible for providing intact equipment and machines at the worksite. If any machine or piece of equipment is found to be faulty, a maintenance technician must be available on site or there should be a properly equipped and staffed workshop on site or close by to do all possible repairs and maintenance. Equipment and machines also need to be replaced in a timely manner with new ones. All workers must be properly qualified and practically trained for every task they are required to perform. Moreover, continuous on-the-job training about safety and occupational hazards at their worksite also need to be a part of every worker's arsenal. The employer and the safety supervisor should assure installing the required safety warning signs about possible hazards at the worksite in each unit. Workers who are at risk of falling from a height should always wear the safety belt and other required PPE "safety harness". In case of any incident or injury, the safety and health supervisor/officer should report and record that incident as accurately as possible. Finally, periodic medical examination of workers shall be carried out to verify their physical condition and abilities are suitable and sufficient for the demands put on them by their employer.

\section{Conclusion}

In conclusion, this study indicates that the causes of occupational accidents and injuries in the construction industry in Jeddah City include the lack of awareness and experience among workers, the deficiency of machines and equipment provided at the worksites, the lack of the proper personal protective equipment, the lack of training and the absence of qualified occupational safety 
supervisors. These factors resulted in unsafe work environments in the construction industry, where the number of injuries and accidents occurred at unacceptable high rates. The most common occupational injuries and accidents that could exist in the construction industry in Jeddah City can include falling from a height, electric shock, and sunstroke. Application of effective control and safety measures at these worksites is a must to eliminate or at least minimize the causes of injuries and accidents. Further investigation and surveying of larger work sites is highly recommended for future studies in the field of occupational health and safety, specifically in the construction industry in the whole of Saudi Arabia.

Table 1. Causes of accidents at your worksite based on age.

\begin{tabular}{c|cccccc}
\hline AGE & $\begin{array}{c}\text { Lack of } \\
\text { awareness } \\
\text { and } \\
\text { experience } \\
\%\end{array}$ & $\begin{array}{c}\text { Machines } \\
\text { defect or } \\
\text { errors\% }\end{array}$ & $\begin{array}{c}\text { Lack of } \\
\text { personal } \\
\text { protection } \\
\text { equipment } \\
\%\end{array}$ & $\begin{array}{c}\text { No safety } \\
\text { and health } \\
\text { officer or } \\
\text { supervisor\% }\end{array}$ & $\begin{array}{c}\text { Unsafe work } \\
\text { environment } \\
\%\end{array}$ & $\begin{array}{c}\text { Lack of } \\
\text { continuous } \\
\text { training\% }\end{array}$ \\
\hline $\mathbf{2 0 - 2 5}$ & $7.33 \%$ & $6.67 \%$ & $2.00 \%$ & $0.67 \%$ & $0.33 \%$ & $2.67 \%$ \\
$\mathbf{2 6 - 3 1}$ & $29.67 \%$ & $23.67 \%$ & $8.00 \%$ & $4.00 \%$ & $4.00 \%$ & $10.00 \%$ \\
$\mathbf{3 2}-\mathbf{3 7}$ & $17.67 \%$ & $12.00 \%$ & $5.00 \%$ & $3.33 \%$ & $3.00 \%$ & $9.67 \%$ \\
$\mathbf{3 8 - 4 3}$ & $17.67 \%$ & $15.00 \%$ & $7.33 \%$ & $3.00 \%$ & $4.33 \%$ & $6.33 \%$ \\
$\mathbf{4 4 - 4 9}$ & $6.33 \%$ & $4.00 \%$ & $1.67 \%$ & $2.67 \%$ & $1.67 \%$ & $2.67 \%$ \\
\hline $\mathbf{5 0}-\mathbf{5 5}$ & $4.00 \%$ & $3.00 \%$ & $1.00 \%$ & $3.33 \%$ & $1.00 \%$ & $1.33 \%$ \\
\hline TOTAL & $\mathbf{8 2 . 6 7 \%}$ & $\mathbf{6 4 . 3 3 \%}$ & $\mathbf{2 5 . 0 0 \%}$ & $\mathbf{1 7 . 0 0 \%}$ & $\mathbf{1 4 . 3 3 \%}$ & $\mathbf{3 2 . 6 7 \%}$ \\
\hline
\end{tabular}

Table 2. Type/s of accident based on age.

\begin{tabular}{|c|c|c|c|c|c|c|c|c|}
\hline AGE & $\begin{array}{c}\text { Falling } \\
\text { from } \\
\text { height } \%\end{array}$ & $\begin{array}{c}\text { Hit with } \\
\text { stationary } \\
\text { equipment } \\
\text { or } \\
\text { machinery } \\
\%\end{array}$ & $\begin{array}{c}\text { Hit with } \\
\text { moving } \\
\text { equipment } \\
\text { or } \\
\text { machinery } \\
\%\end{array}$ & $\begin{array}{c}\text { Falling of } \\
\text { the } \\
\text { equipment } \\
\text { on the } \\
\text { head\% }\end{array}$ & $\begin{array}{r}\text { Electric } \\
\text { shock\% }\end{array}$ & $\begin{array}{c}\text { Exposure } \\
\text { to } \\
\text { chemicals } \\
\%\end{array}$ & $\begin{array}{c}\text { Material } \\
\text { handling } \\
\text { incidents } \\
\%\end{array}$ & $\begin{array}{c}\text { Car } \\
\text { accidents } \\
\text { (transfer } \\
\text { objects } \\
\text { from site } \\
\text { to } \\
\text { another) } \\
\%\end{array}$ \\
\hline $20-25$ & $8.00 \%$ & $0.67 \%$ & $0.33 \%$ & $3.00 \%$ & $2.67 \%$ & $1.00 \%$ & $1.33 \%$ & $0.00 \%$ \\
\hline $26-31$ & $27.67 \%$ & $6.33 \%$ & $6.33 \%$ & $8.67 \%$ & $12.00 \%$ & $3.00 \%$ & $7.33 \%$ & $4.33 \%$ \\
\hline $32-37$ & $17.33 \%$ & $7.33 \%$ & $5.33 \%$ & $7.67 \%$ & $11.33 \%$ & $2.67 \%$ & $5.33 \%$ & $3.00 \%$ \\
\hline $38-43$ & $18.00 \%$ & $7.00 \%$ & $7.00 \%$ & $5.33 \%$ & $6.33 \%$ & $2.33 \%$ & $6.67 \%$ & $3.67 \%$ \\
\hline $44-49$ & $6.33 \%$ & $2.00 \%$ & $1.67 \%$ & $1.67 \%$ & $4.00 \%$ & $1.00 \%$ & $2.67 \%$ & $1.33 \%$ \\
\hline $50-55$ & $4.00 \%$ & $1.00 \%$ & $2.67 \%$ & $1.00 \%$ & $2.00 \%$ & $1.00 \%$ & $2.00 \%$ & $2.67 \%$ \\
\hline TOTAL & $81.33 \%$ & $24.33 \%$ & $23.33 \%$ & $27.33 \%$ & $38.33 \%$ & $11.00 \%$ & $25.33 \%$ & $15.00 \%$ \\
\hline
\end{tabular}


Table 3. Type/s of injury based on age.

\begin{tabular}{|c|c|c|c|c|c|c|c|c|c|c|c|}
\hline AGE & 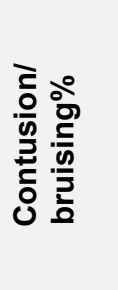 & 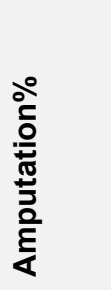 & 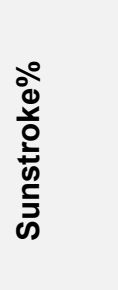 & 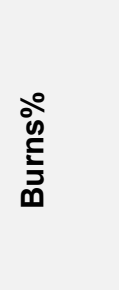 & 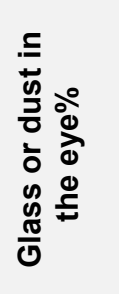 & 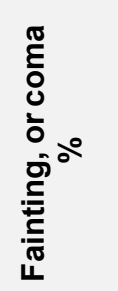 & $\begin{array}{l}\text { ò } \\
\text { in } \\
\stackrel{0}{5} \\
0 \\
3\end{array}$ & 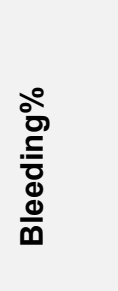 & 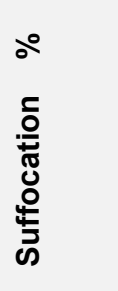 & 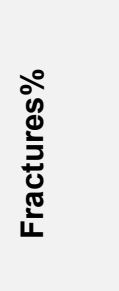 & 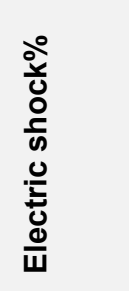 \\
\hline $20-25$ & $0.67 \%$ & 0.3 & $3.00 \%$ & $0.00 \%$ & $0.67 \%$ & $0.33 \%$ & $0.67 \%$ & $0.33 \%$ & $0.33 \%$ & $0.00 \%$ & $9.67 \%$ \\
\hline $26-31$ & $8.33 \%$ & $4.67 \%$ & $9.67 \%$ & $5.00 \%$ & $6.00 \%$ & $6.33 \%$ & $7.00 \%$ & $5.00 \%$ & $3.33 \%$ & $6.33 \%$ & $23.00 \%$ \\
\hline $32-37$ & $8.00 \%$ & $6.67 \%$ & $9.67 \%$ & $4.00 \%$ & $6.00 \%$ & $3.33 \%$ & $5.00 \%$ & $5.00 \%$ & $3.67 \%$ & $6.00 \%$ & $12.67 \%$ \\
\hline $38-43$ & $8.33 \%$ & $7.00 \%$ & $7.33 \%$ & $4.00 \%$ & $5.67 \%$ & $3.33 \%$ & $6.00 \%$ & $6.67 \%$ & $3.33 \%$ & $6.67 \%$ & $11.33 \%$ \\
\hline $44-49$ & $3.00 \%$ & $3.67 \%$ & $1.67 \%$ & $1.33 \%$ & $1.00 \%$ & $1.67 \%$ & $3.33 \%$ & $3.33 \%$ & $1.00 \%$ & $2.33 \%$ & $2.33 \%$ \\
\hline $50-55$ & $1.33 \%$ & $3.33 \%$ & $1.33 \%$ & $1.00 \%$ & $1.00 \%$ & $1.00 \%$ & $2.33 \%$ & $2.67 \%$ & $1.00 \%$ & $3.67 \%$ & $2.00 \%$ \\
\hline TOTAL & $\begin{array}{c}29.67 \\
\% \\
\end{array}$ & $\begin{array}{c}25.67 \\
\% \\
\end{array}$ & $\begin{array}{c}32.67 \\
\% \\
\end{array}$ & $\begin{array}{c}15.33 \\
\% \\
\end{array}$ & $\begin{array}{c}20.33 \\
\% \\
\end{array}$ & $\begin{array}{c}16.00 \\
\% \\
\end{array}$ & $\begin{array}{c}24.33 \\
\% \\
\end{array}$ & $\begin{array}{c}23.00 \\
\%\end{array}$ & $\begin{array}{c}12.67 \\
\% \\
\end{array}$ & $\begin{array}{c}25.00 \\
\% \\
\end{array}$ & $61.00 \%$ \\
\hline
\end{tabular}

Table 4. Causes of accidents at your worksite based on years of experience.

\begin{tabular}{c|cccccc}
\hline $\begin{array}{c}\text { YEARS OF } \\
\text { EXPERIENCE }\end{array}$ & $\begin{array}{c}\text { Lack of } \\
\text { awareness } \\
\text { and } \\
\text { experience } \\
\text { \% }\end{array}$ & $\begin{array}{c}\text { Machines } \\
\text { defect or } \\
\text { errors\% }\end{array}$ & $\begin{array}{c}\text { Lack of } \\
\text { personal } \\
\text { protection } \\
\text { equipment }\end{array}$ & $\begin{array}{c}\text { No safety } \\
\text { and health } \\
\text { officer or } \\
\text { supervisor\% }\end{array}$ & $\begin{array}{c}\text { Unsafe work } \\
\text { environment } \\
\%\end{array}$ & $\begin{array}{c}\text { Lack of } \\
\text { continuous } \\
\text { training\% }\end{array}$ \\
$\mathbf{0 - 5}$ & $13.00 \%$ & $7.67 \%$ & $3.00 \%$ & $2.67 \%$ & $1.33 \%$ & $5.00 \%$ \\
$\mathbf{6 - - 1 1}$ & $38.00 \%$ & $29.33 \%$ & $10.67 \%$ & $7.00 \%$ & $5.00 \%$ & $14.33 \%$ \\
$\mathbf{1 2 - - 1 7}$ & $18.33 \%$ & $16.00 \%$ & $6.00 \%$ & $3.67 \%$ & $4.33 \%$ & $7.67 \%$ \\
$\mathbf{1 8 - - 2 3}$ & $12.33 \%$ & $10.33 \%$ & $4.67 \%$ & $3.33 \%$ & $3.00 \%$ & $4.67 \%$ \\
$\mathbf{2 4 - - 2 9}$ & $1.00 \%$ & $1.00 \%$ & $0.67 \%$ & $0.33 \%$ & $0.67 \%$ & $1.00 \%$ \\
TOTAL & $\mathbf{8 2 . 6 7 \%}$ & $\mathbf{6 4 . 3 3 \%}$ & $\mathbf{2 5 . 0 0 \%}$ & $\mathbf{1 7 . 0 0 \%}$ & $\mathbf{1 4 . 3 3 \%}$ & $\mathbf{3 2 . 6 7 \%}$ \\
\hline
\end{tabular}

Table 5. Type/s of accident based on years of experience.

\begin{tabular}{|c|c|c|c|c|c|c|c|c|}
\hline $\begin{array}{c}\text { YEARS OF } \\
\text { EXPERIENC } \\
E\end{array}$ & $\begin{array}{c}\text { Falling } \\
\text { from } \\
\text { height } \%\end{array}$ & $\begin{array}{c}\text { Hit with } \\
\text { stationary } \\
\text { equipment } \\
\text { or } \\
\text { machinery } \\
\%\end{array}$ & $\begin{array}{c}\text { Hit with } \\
\text { moving } \\
\text { equipment } \\
\text { or } \\
\text { machinery } \\
\%\end{array}$ & $\begin{array}{l}\text { Falling of } \\
\text { the } \\
\text { equipme } \\
\text { nt on the } \\
\text { head\% }\end{array}$ & $\begin{array}{r}\text { Electric } \\
\text { shock\% }\end{array}$ & $\begin{array}{c}\text { Exposure } \\
\text { to } \\
\text { chemical } \\
s \%\end{array}$ & $\begin{array}{c}\text { Material } \\
\text { handling } \\
\text { incident } \\
\mathbf{s} \%\end{array}$ & $\begin{array}{c}\text { Car } \\
\text { accident } \\
\text { s } \\
\text { (transfer } \\
\text { objects } \\
\text { from site } \\
\text { to } \\
\text { another) } \\
\%\end{array}$ \\
\hline $0-5$ & $11.67 \%$ & $2.33 \%$ & $1.00 \%$ & $5.33 \%$ & $5.33 \%$ & $1.67 \%$ & $2.67 \%$ & $1.67 \%$ \\
\hline $6--11$ & $37.33 \%$ & $13.00 \%$ & $9.33 \%$ & $11.33 \%$ & $18.67 \%$ & $3.33 \%$ & $11.33 \%$ & $5.00 \%$ \\
\hline $12--17$ & $18.67 \%$ & $5.67 \%$ & $6.33 \%$ & $6.00 \%$ & $8.33 \%$ & $3.33 \%$ & $5.67 \%$ & $3.33 \%$ \\
\hline $18--23$ & $12.67 \%$ & $2.33 \%$ & $6.00 \%$ & $4.00 \%$ & $5.00 \%$ & $2.00 \%$ & $5.00 \%$ & $4.33 \%$ \\
\hline 24--29 & $1.00 \%$ & $1.00 \%$ & $0.67 \%$ & $0.67 \%$ & $1.00 \%$ & $0.67 \%$ & $0.67 \%$ & $0.67 \%$ \\
\hline TOTAL & $81.33 \%$ & $24.33 \%$ & $23.33 \%$ & $27.33 \%$ & $38.33 \%$ & $11.00 \%$ & $25.33 \%$ & $15.00 \%$ \\
\hline
\end{tabular}


Table 6. TYPE/s of injury based on years of experience.

\begin{tabular}{|c|c|c|c|c|c|c|c|c|c|c|c|}
\hline 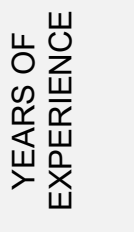 & 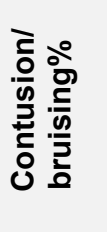 & 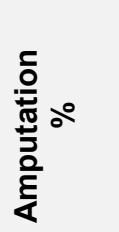 & 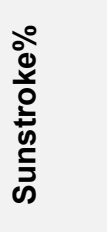 & ồ & 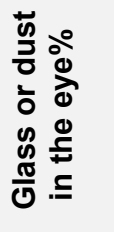 & 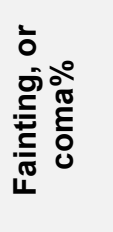 &  & 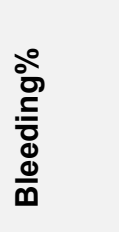 & 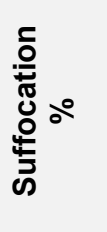 & 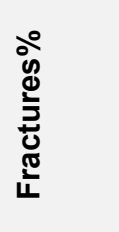 & 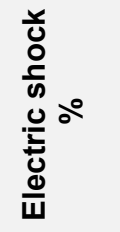 \\
\hline $0-5$ & $2.67 \%$ & $2.33 \%$ & $6.33 \%$ & $1.33 \%$ & $2.67 \%$ & $1.33 \%$ & $3.33 \%$ & $2.67 \%$ & $1.00 \%$ & $2.67 \%$ & $9.00 \%$ \\
\hline $6-11$ & $\begin{array}{c}13.67 \\
\%\end{array}$ & $\begin{array}{c}11.33 \\
\%\end{array}$ & $\begin{array}{c}14.00 \\
\%\end{array}$ & $7.33 \%$ & $7.00 \%$ & $5.00 \%$ & $9.33 \%$ & $9.33 \%$ & $5.67 \%$ & $9.67 \%$ & $27.00 \%$ \\
\hline $12-17$ & $7.00 \%$ & $4.00 \%$ & $8.00 \%$ & $3.67 \%$ & $6.67 \%$ & $6.67 \%$ & $5.33 \%$ & $5.00 \%$ & $3.33 \%$ & $5.67 \%$ & $16.33 \%$ \\
\hline $18-23$ & $5.33 \%$ & $7.33 \%$ & $3.33 \%$ & $2.33 \%$ & $3.33 \%$ & $2.33 \%$ & $5.67 \%$ & $5.00 \%$ & $2.00 \%$ & $6.33 \%$ & $8.00 \%$ \\
\hline 24-29 & $1.00 \%$ & $0.67 \%$ & $1.00 \%$ & $0.67 \%$ & $0.67 \%$ & $0.67 \%$ & $0.67 \%$ & $1.00 \%$ & $0.67 \%$ & $0.67 \%$ & $0.67 \%$ \\
\hline TOTAL & $\begin{array}{c}29.67 \\
\%\end{array}$ & $\begin{array}{c}25.67 \\
\%\end{array}$ & $\begin{array}{c}32.67 \\
\%\end{array}$ & $\begin{array}{c}15.33 \\
\%\end{array}$ & $\begin{array}{c}20.33 \\
\%\end{array}$ & $\begin{array}{c}16.00 \\
\%\end{array}$ & $\begin{array}{c}24.33 \\
\%\end{array}$ & $\begin{array}{c}23.00 \\
\%\end{array}$ & $\begin{array}{c}12.67 \\
\%\end{array}$ & $\begin{array}{c}25.00 \\
\%\end{array}$ & $61.00 \%$ \\
\hline
\end{tabular}

Table 7. Causes of accidents at your worksite based on education.

\begin{tabular}{|c|cccccc}
\hline EDUCATION & $\begin{array}{c}\text { Lack of } \\
\text { awareness } \\
\text { and } \\
\text { experience } \\
\%\end{array}$ & $\begin{array}{c}\text { Machines } \\
\text { defect or } \\
\text { errors } \%\end{array}$ & $\begin{array}{c}\text { Lack of } \\
\text { personal } \\
\text { protection } \\
\text { equipment } \\
\%\end{array}$ & $\begin{array}{c}\text { No safety } \\
\text { and health } \\
\text { officer or } \\
\text { supervisor } \\
\%\end{array}$ & $\begin{array}{c}\text { Unsafe work } \\
\text { environment } \\
\%\end{array}$ & $\begin{array}{c}\text { Lack of } \\
\text { continuous } \\
\text { training }\end{array}$ \\
$\begin{array}{c}\text { NONE } \\
15.33 \%\end{array}$ & $20.00 \%$ & $5.33 \%$ & $1.67 \%$ & $0.33 \%$ & $2.00 \%$ \\
$\begin{array}{c}\text { ELEMENTARY } \\
\text { EDUCATION - MIDDLE } \\
\text { - SECONDARY }\end{array}$ & $37.33 \%$ & $31.00 \%$ & $5.33 \%$ & $9.67 \%$ & $4.00 \%$ & $5.67 \%$ \\
HIGHER EDUCATION & $30.00 \%$ & $13.33 \%$ & $14.33 \%$ & $5.67 \%$ & $10.00 \%$ & $25.00 \%$ \\
TOTAL & $82.67 \%$ & $64.33 \%$ & $25.00 \%$ & $17.00 \%$ & $14.33 \%$ & $32.67 \%$ \\
\hline
\end{tabular}

Table 8. Type/s of accident based on education.

\begin{tabular}{|c|c|c|c|c|c|c|c|c|}
\hline EDUCATION & $\begin{array}{c}\text { Falling } \\
\text { from } \\
\text { height } \%\end{array}$ & $\begin{array}{c}\text { Hit with } \\
\text { stationary } \\
\text { equipmen } \\
\text { t or } \\
\text { machiner } \\
\text { y\% }\end{array}$ & $\begin{array}{l}\text { Hit with } \\
\text { moving } \\
\text { equipmen } \\
\text { t or } \\
\text { machiner } \\
\text { y\% }\end{array}$ & $\begin{array}{l}\text { Falling of } \\
\text { the } \\
\text { equipme } \\
\text { nt on the } \\
\text { head } \%\end{array}$ & $\begin{array}{l}\text { Electric } \\
\text { shock\% }\end{array}$ & $\begin{array}{c}\text { Exposure } \\
\text { to } \\
\text { chemical } \\
\mathbf{s} \%\end{array}$ & $\begin{array}{c}\text { Material } \\
\text { handling } \\
\text { incident } \\
\mathbf{s} \%\end{array}$ & $\begin{array}{c}\text { Car } \\
\text { accidents } \\
\text { (transfer } \\
\text { objects } \\
\text { from site } \\
\text { to } \\
\text { another) } \\
\%\end{array}$ \\
\hline NONE & $23.67 \%$ & $3.33 \%$ & $4.33 \%$ & $3.33 \%$ & $5.33 \%$ & $0.00 \%$ & $0.67 \%$ & $0.00 \%$ \\
\hline 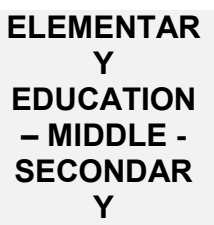 & $35.67 \%$ & $6.67 \%$ & $7.00 \%$ & $2.67 \%$ & $12.00 \%$ & $0.67 \%$ & $10.00 \%$ & $3.67 \%$ \\
\hline $\begin{array}{c}\text { HIGHER } \\
\text { EDUCATION }\end{array}$ & $22.00 \%$ & $14.33 \%$ & $12.00 \%$ & $21.33 \%$ & $21.00 \%$ & $10.33 \%$ & $13.00 \%$ & $11.00 \%$ \\
\hline TOTAL & $81.33 \%$ & $24.33 \%$ & $23.33 \%$ & $27.33 \%$ & $38.33 \%$ & $11.00 \%$ & $23.67 \%$ & $14.67 \%$ \\
\hline
\end{tabular}


Table 9. Type/s of injury based on education.

\begin{tabular}{|c|c|c|c|c|c|c|c|c|c|c|c|}
\hline EDUCATION & 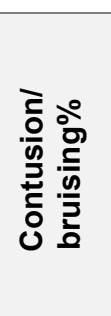 & 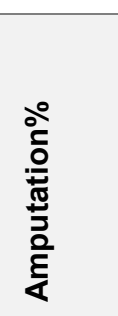 & 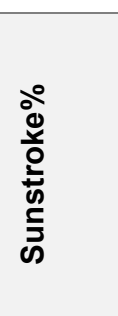 & 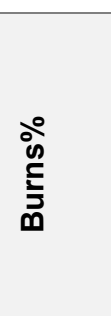 & 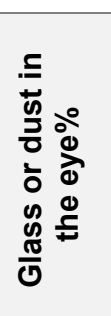 & 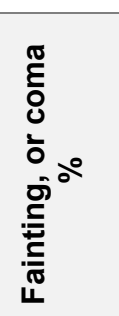 & $\begin{array}{l}\text { ò } \\
\text { in } \\
\vdots \\
\vdots \\
3\end{array}$ & $\begin{array}{l}\stackrel{0}{0} \\
\stackrel{5}{0} \\
\frac{\Phi}{0} \\
\frac{0}{0}\end{array}$ & 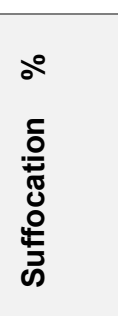 & 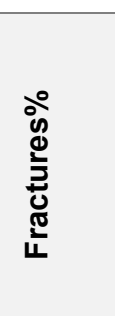 & 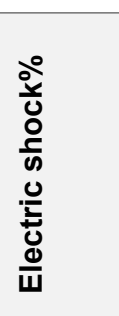 \\
\hline NONE & $7.67 \%$ & $1.00 \%$ & $3.67 \%$ & $1.00 \%$ & $3.67 \%$ & $1.00 \%$ & $1.33 \%$ & $1.33 \%$ & $0.33 \%$ & $0.67 \%$ & $16.67 \%$ \\
\hline $\begin{array}{c}\text { ELEMENTARY } \\
\text { EDUCATION - } \\
\text { MIDDLE - } \\
\text { SECONDARY }\end{array}$ & $\begin{array}{c}11.33 \\
\%\end{array}$ & $\begin{array}{c}14.33 \\
\%\end{array}$ & $3.67 \%$ & $2.33 \%$ & $4.00 \%$ & $2.67 \%$ & $\begin{array}{c}10.67 \\
\%\end{array}$ & $\begin{array}{c}10.33 \\
\%\end{array}$ & $1.00 \%$ & $9.33 \%$ & $21.00 \%$ \\
\hline $\begin{array}{l}\text { HIGHER } \\
\text { EDUCATION }\end{array}$ & $\begin{array}{c}10.67 \\
\%\end{array}$ & $\begin{array}{c}10.33 \\
\%\end{array}$ & $\begin{array}{c}25.33 \\
\%\end{array}$ & $\begin{array}{c}12.00 \\
\%\end{array}$ & $\begin{array}{c}12.67 \\
\%\end{array}$ & $\begin{array}{c}12.33 \\
\%\end{array}$ & $\begin{array}{c}12.33 \\
\%\end{array}$ & $\begin{array}{c}11.33 \\
\%\end{array}$ & $\begin{array}{c}11.33 \\
\%\end{array}$ & $\begin{array}{c}15.00 \\
\%\end{array}$ & $23.33 \%$ \\
\hline TOTAL & $\begin{array}{c}29.67 \\
\%\end{array}$ & $\begin{array}{c}25.67 \\
\%\end{array}$ & $\begin{array}{c}32.67 \\
\%\end{array}$ & $\begin{array}{c}15.33 \\
\%\end{array}$ & $\begin{array}{c}20.33 \\
\%\end{array}$ & $\begin{array}{c}16.00 \\
\%\end{array}$ & $\begin{array}{c}24.33 \\
\%\end{array}$ & $\begin{array}{c}23.00 \\
\%\end{array}$ & $\begin{array}{c}12.67 \\
\%\end{array}$ & $\begin{array}{c}25.00 \\
\%\end{array}$ & $61.00 \%$ \\
\hline
\end{tabular}

\section{References}

Abbas RA, Zalat MM and Ghareeb NSE. (2013). Non-Fatal Occupational Injuries and Safety Climate: A CrossSectional Study of Construction Building Workers in MitGhamr City, Dakahlia Governorate, Egypt. Open Journal of Safety Science and Technology, 3(04): 69.

Abdul Hamid AR, Yusuf WZW and Singh B. (2003) "Hazards at construction sites". Proceedings of the 5th Asia-Pacific Structural Engineering and Construction Conference. Johor Bahru, Malaysia.

Awad AJ. (2013). Construction safety in Kingdom of Saudi Arabia (Doctoral dissertation, Eastern Mediterranean University (EMU)-Doğu Akdeniz Üniversitesi (DAÜ).

BLS, Work place injuries and illnesses in 2005, B.o.L. Statistics, Editor 2006.

Cawley JC and Homce GT. (2003). Occupational electrical injuries in the United States, 1992-1998, and recommendations for safety research. Journal of safety research, 34(3): 241-248.

Colak B, Etiler N and Bicer U. (2004). Fatal occupational injuries in the construction sector in Kocaeli, Turkey, 1990-2001. Industrial health, 42(4): 424-430.

DeJoy DM, Schaffer BS, Wilson MG, et al. (2004). Creating safer workplaces: assessing the determinants and role of safety climate. Journal of safety research, 35(1): 81-90.

EL-Nakhlawy, F.S. (2010). Experimental Design and Analysis in scientific Research. Sci. Pub. Center, King Abdulaziz University, Jeddah, Saudi Arabia.

Enshassi A and Mohammaden A. (2012). Occupational deaths and injuries in the construction industry.

General Authority of Meteorology and Environmental Protection. (2018). Available at:
https://www.pme.gov.sa/En/Weather/pages/default.aspx. Accessed May 20, 2018.

GOSI. (2015). Annual statistical report 1435H. Available at: http://www.gosi.gov.sa/portal/web/guest/statistics/viewstatistic?StatisticsId=1379226. Accessed February, 11, 2018.

Gürcanli GE and Müngen U. (2009). An occupational safety risk analysis method at construction sites using fuzzy sets. International Journal of Industrial Ergonomics, 39(2): 371-387.

Hare B, Cameron I and Roy Duff A. (2006). Exploring the integration of health and safety with pre-construction planning. Engineering, construction and architectural management, 13(5), 438-450.

Hassan CC, Basha OJ and Hanafi WW. (2007). Perception of building construction workers towards safety, health and environment. Journal of Engineering Science and technology, 2(3): 271-279

Helander MG. (1991). Safety hazards and motivation for safe work in the construction industry. International Journal of Industrial Ergonomics, 8(3): 205-223.

Hinze J, Huang $\mathbf{X}$ and Terry L. (2005). The nature of struckby accidents. Journal of construction engineering and management, 131(2): 262-268.

Im HJ, Kwon YJ, Kim, S et al. (2009). The characteristics of fatal occupational injuries in Korea's construction industry, 1997-2004. Safety Science, 47(8): 1159-1162.

Kadiri ZO, Nden T, Avre GK, et al. (2014). Causes and Effects of Accidents on Construction Sites (A Case Study of Some Selected Construction Firms in Abuja, FCT Nigeria). IOSR Journal of Mechanical and Civil Engineering, 11(5): 66-72. 
Kalatpour O and Khavaji S. (2016). Occupational injuries overview: general descriptive study of the petrochemical construction industries. Caspian journal of health research, 2(1): 37-43.

Kartam NA and Bouz RG. (1998). Fatalities and injuries in the Kuwaiti construction industry. Accident analysis \& prevention, 30(6): 805-814.

Kumar PS and Kumar ML. (2012). Viability of Safety and Labour Conditions in Construction Sites. International Journal of Engineering and Innovative Technology, 2(6): 328-332.

Mohan S and Zech WC. (2005). Characteristics of worker accidents on NYSDOT construction projects. Journal of Safety Research, 36(4): 353-360.

Mosly I. (2015). Safety performance in the construction industry of Saudi Arabia. International Journal of Construction Engineering and Management, 4(6): 238247.

Occupational Safety and Health Administration (OSHA). Construction Industry. Available at: https://www.osha.gov/doc/index.html. Accessed May 10, 2018.

Pinto A, Nunes IL and Ribeiro RA. (2011). Occupational risk assessment in the construction industry - Overview and reflection. Safety Science, 49(5): 616-624.

Prasad SR and Rao YP. (2013). Study on Validation of Wholesaler Selection of Personal Protective Equipment to Improve Safety Performance in a Construction Organization in India. International Journal of Managing Value and Supply Chains, 4(2): 17.

Roudsari BS and Ghodsi M. (2005). Occupational injuries in Tehran. Injury, 36(1): 33-39.

Sawacha E, Naoum S and Fong D. (1999). Factors affecting safety performance on construction sites. International journal of project management, 17(5): 309-315
Sousa V, Almeida NM and Dias LA. (2014). Risk-based management of occupational safety and health in the construction industry - Part 1: Background knowledge. Safety Science, 66: 75-86.

Tadesse S and Israel D. (2016). Occupational injuries among building construction workers in Addis Ababa, Ethiopia. Journal of Occupational Medicine and Toxicology, 11(1): 16.

Tam CM, Zeng SX and Deng ZM. (2004). Identifying elements of poor construction safety management in China. Safety Science, 42(7): 569-586.

Tappin D, Ashly L, Moore D, et al. (2004). Slip, Trip and Falls In Residential Construction. Journal of Centre for Human Factors and Ergonomics, 5(4): 1174-1234.

Taylor AJ, McGwin G, Valent F and Rue LW. (2002). Fatal occupational electrocutions in the United States. Injury Prevention, 8(4): 306-312.

The National Institute for Occupational Safety and Health (NIOS). (2018). Directory of NIOSH Construction Resources. Available at: https://www.cdc.gov/niosh/construction/default.html. Accessed May 10, 2018.

Vouriot A, Gauchard GC, Chau N, et al. (2004). Sensorial organization favouring higher visual contribution is a risk factor of falls in an occupational setting. Neuroscience research, 48(3): 239-247.

Wadick P. (2010). Safety culture among subcontractors in the domestic housing construction industry. Structural Survey, 28(2): 108-120.

Waehrer GM, Dong XS, Miller T, Haile E and Men Y. (2007). Costs of occupational injuries in construction in the United States. Accident Analysis \& Prevention, 39(6): 1258-1266. 
أسباب الحو ادث و الإصابات المهنية في صناعة النتيبد و البناء في مدينة جدة عماد أبو خشبة، و أحمد صمان، و منصور بالخيور

قسم العلوم البيئية، كلية الأرصاد والبيئة وزراعة العناطق الجافة، جامعة الملك عبد العزبي، جدة،

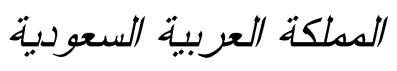

asumman@kau.edu.sa

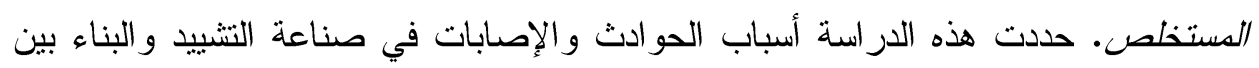
. . . Fامل في مدينة جدة، الو اقعة على البحر الأحمر من الملكة العربية السعودية. بينت

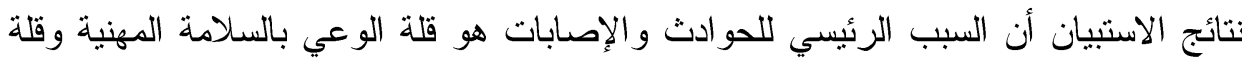

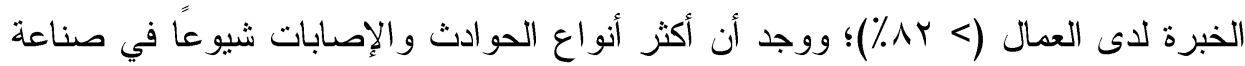

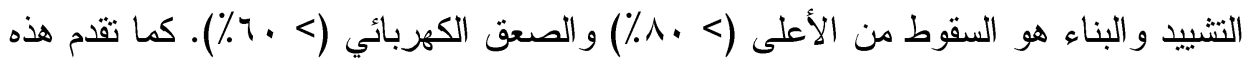
الدراسة بعض التوصيات للحد من وقوع الحو ادث و الإصابات في صناعة النتييد و البناء. الكلمات الدفتاحية: صناعة النتييد و البناء، الحوادث والإصابات في صناعة التثييد و البناء،

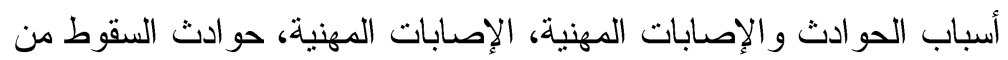
الأعلى، حو ادث الصعق الكهربائي. 